\title{
IT Integration, Operations Flexibility and Performance: An Empirical Study
}

\author{
María Esther Caracuel Martínez(D), Daniel Arias Aranda (D), Leopoldo Gutiérrez GutiérreziD \\ Universidad de Granada (Spain) \\ mcaracuel@ugr.es,_darias@ugr.es, leogo@ugr.es
}

Received: January 2016

Accepted: July 2016

Abstract:

Purpose: This study examines the relationship between IT implementation and performance with manufacturing flexibility based on a sample drawn from a set of manufacturing firms.

Design/methodology/approach: The relationships were analyzed using structural equations modelling (SEM) using EQS 6.2 software. Previously, an explanatory factor analysis confirmed one-dimensionality of the scales, Cronbach's alpha was calculated to evaluate its internal consistency and a confirmatory factor analysis was run to observe scales' validity.

Findings: This research proves a significant positive and direct effect of IT implementation on operations performance with 4 out of 6 flexibility dimensions (Machine, Labour, Material handling and Volume). Mix and Routing flexibility dimensions show no significant impact on firm performance.

Research limitations/implications: It is necessary to be cautious when generalizing this findings these findings, as service firms were not part of the sample even when statistical results prove robustness suggesting that the findings are quite reliable. Some flexibility dimensions show no significant impact in performance (Routing and Mix flexibility). This is consistent with the fact that these flexibility dimensions act as variability absorbers within the manufacturing process.

Future research lines: Future studies can focus on determining further internal and environmental factors that affect operations flexibility according to specific sector characteristics. 
Originality/value: This research proves a significant positive and direct effect of IT implementation on operations performance. Results show not only the links between IT implementation and operations performance, but also the magnitude of every impact. The model considers IT integration as the degree of alignment that existing technology resources in a firm have with the business strategy, in terms of importance and support for this strategy.

Keywords: IT integration, manufacturing flexibility, performance, strategy, complementarity perspective

\section{Introduction}

In the last decades, operations and manufacturing flexibility has received an increasing attention in literature due to its crucial importance for maintaining a competitive advantage that leads to higher levels of performance (Oke, 2005). In today's uncertain and changing environment, manufacturing flexibility plays an essential role related to supply chain management, especially regarding the process of rapid and constant introduction of new products on the market (Stevens, 1989; Markus, Steinfield \& Wigand, 2006; Numilaakso, 2008). In this context, different studies have analyzed whether it is advisable for firms to adopt and invest in Information Technologies (IT) that allows a better supply chain integration with suppliers and customers not only in terms of information exchange but also for resources optimization (see among others Ageron, Gunasekaran \& Spalanzi, 2013; Chan \& Chan, 2009; Vickery, Droge, Setia \& Sambamurthy, 2010; Zhang \& Dhaliwal, 2009). Literature supports the strategic value of IT by stressing the capability of IT's to receive, process, and transmit information in real time, thereby facilitating coordination, flexibility, optimization and decision making in real time (Sanders \& Premus, 2002; Vickery et al., 2010; Zhang \& Dhaliwal, 2009). Hence, IT and operations flexibility are undeniably a strategic priority for firms (Sawhney, 2006). Hence, IT and operations flexibility are undeniably a strategic priority for firms (Sawhney, 2006). The relationship between IT and manufacturing flexibility has been analyzed from different external and internal perspectives. While some studies tackle the strategic capability of IT's from its capability to determine the competitive priorities of the firm to increase competitiveness (Arias-Aranda, 2003); other studies start from an internal focus and sustain that the firm's resources and capabilities with IT integration directly increase competitiveness of the firm (Schmenner \& Tatikonda, 2005). Despite this difference, recent literature has analyzed these elements within the supply chain perspective outlining the impact of internal lacks and weaknesses when IT implementation is not aligned with manufacturing and supply processes (Ranganathan, Dhaliwal \& Teo, 2004; Vickery et al., 2010). This fact is especially compelling when it involves firms configuring common parts of the supply chain (Zhang \& Dhaliwal, 2009). 
This study examines the relationship between IT implementation and performance with manufacturing flexibility. IT implementation is a costly investment for firms which could lead to support the development of manufacturing flexibility and to obtain higher levels of performance (Giménez, Van der Vaart \& van Donk, 2012). IT integration and flexibility have been considered as antecedents for achieving agility in the supply chain in previous studies (Swafford, Ghosh \& Murthy, 2008). It is essential to develop in greater depth the idea that supply chain can involve multiple organizations with cross effects in performance. Internal integration can improve the different dimensions of flexibility and, as a result, improve internal efficiency, increasing performance for the supply chain. Based on these considerations, our conceptual model does not attribute direct impact on performance to IT per se but instead views it as adding competitive value to operating performance with the action of flexibility. From an academic perspective, this study provides an analysis of operating flexibility from a perspective of complementarity among organizational resources to increase performance.

This paper is structured as follows. In the next section, the theoretical basis of IT, manufacturing flexibility and performance is presented as well as an analysis of the linkages among them from the perspective of the complementarity approach (Milgrom \& Roberts, 1995) and the Theory of Resources and Capabilities (Nelson \& Winter, 1992) to state the hypotheses of the study. The next section presents the research methodology, sample and data collection as well as the measurement of the different variables involved in the study. After that, results will be discussed. In the last section, the implications of the findings, limitations of the study and academic and practitioners implications will be disclosed together with limitations of the study and future lines of research.

\section{Theoretical Review and Hypothesis Development}

\subsection{Integration of Information Technologies into Business Strategy and its Impact on Operating} Flexibility

IT integration impact on performance has been analyzed considering different IT dimensions such as investment in IT, adoption of specific information systems, and IT infrastructure (Mitra \& Chaya, 1996; Tam, 1998). There are studies that consider management aspects directly affected by IT implementation such as management abilities, employee training or knowledge management (Ranganathan et al., 2004; Bhatt, Grover \& Grover, 2005). Recently, practices of integration with "key" customers have received specific attention regarding its high complexity (Giménez et al., 2012).

Literature has shown the positive relationship between investment in IT, productivity, profitability, and even customer satisfaction (Hitt \& Brynjolfsson, 1996). However, more recent studies suggest that IT 
benefits are strengthened only when synergy with other investments or complementary resources are achieved not only within business processes but also amidst capabilities (Ray, Muhanna \& Barney, 2005; Tanriverdi, 2006; Zhu, 2002). In terms of the strategic goal of the IT integration process, Ranganathan et al. (2004) findings support the fact that IT implementation ameliorates the firm's internal operations (ebusiness intranets) while improving supply chain even in e-business extranets. In both cases, there are cross effects from internal and external outcomes (Melville, Kraemer \& Gurbaxani, 2004; Zhang \& Dhaliwal, 2009). Some of these internal outcomes are related to organizational issues for internal diffusion of IT such as formalization of IT deployment, knowledge management as well as integration of manager's abilities (Barney, 1991; Swanson, 1994). External outcomes are more related to technological issues for IT external diffusion among suppliers, customers, partners, etc (Chwelos, Benbasar \& Dexter, 2001). The intensity of the interdependence of the firm with its suppliers, customers or partners will shape the intensity with which they deploy ITs in the supply chain (Zhu, Kraemer \& Xu, 2006). Hence, the intensity of competence, or the so-called "positive effect of competence" drives other firms to adopt technologies to improve their operating efficiency and coordination with other partners in the supply chain increasing the intensity of IT integration deployed throughout the supply chain (Zhu et al., 2006).

Operations flexibility as competitive priority has received plenty of attention from the academic community in the last decades for manufacturing as well as service industries. Despite there has been a clear evolution in the concept still no clear consensus about the definition of flexibility has been settled (see among others Baykasoglu \& Özbakir, 2008; Beach, Muhlemann, Price, Paterson \& Sharp, 2000; Francas, Kremer, Minner \& Friese, 2009; Koste \& Malhotra, 1999; Mihi-Ramírez, García-Morales, Arias-Aranda, 2012; Oke, 2005; Prahalad \& Hamel, 1990; Sethi \& Sethi, 1990; Teece, Pisano \& Shuen, 1997; De Toni \& Tonchia, 1998; Upton, 1997; Vokurka \& O'Leary-Kelli, 2000). Notwithstanding, all studies agree that flexible organizations are those which have developed the ability to generate new products rapidly and often that are able to vary production volume without incurring into higher costs, time, or performance. Therefore, operations flexibility allows firms to respond to threats from competitors and fulfil customer's expectations in time and place (Swafford et al., 2008; Upton, 1997; Zhang, Vonderembse \& Lim, 2003).

There is a growing interest in literature to determine how IT implementation influences operations flexibility (Mihi-Ramírez, García-Morales, Arias-Aranda, 2012; Petersen, Handfield \& Ragatz, 2005; Soroor, Tarokh \& Keshtgary, 2009). IT integration requires high levels of coordination among all functional areas of the firm as well as full cohesion of activities and processes with customers, partners and suppliers in order to achieve a common improvement of performance (Avittathur \& Swamidass, 2007; Flynn, Huo \& Zhao, 2010; Frohlich \& Westbrook, 2001; Petersen et al., 2005; Stank, Keller \& Daugherty, 2001). In this context, Swafford, Ghosh and Murthy (2006) found a direct and positive relationship between the agility of a firm's supply chain and the flexibility of the supply chain processes. 
This relationship is reinforced when operations and other functional processes are previously integrated such like inventory management, new product development and even interfunctional relations (Das, Narasimham \& Talluri, 2006) which drives the firm towards optimizing the IT adoption and implementation process (Zhang, Vonderembse \& Cao, 2006). Consequently, integration of IT in the business strategy for decision making and improvement in internal efficiency involves higher flexibility due to an increased real time control and effectiveness in decision making regarding production planning and programming among others (Jin, Vonderembse, Ragu-Nathan \& Smith, 2014).

Gerwin (1993) identifies 7 dimensions of manufacturing flexibility accordingly to different types of uncertainty and strategic goals. These dimensions help operations managers to prioritize which dimension(s) of flexibility must be strengthened according to achieve every strategic goal. Table 1 shows how the initial four dimensions of flexibility are associated with market-oriented uncertainties, particularly those related to products demand. The next three dimensions are more related to uncertainties regarding manufacturing processes (see Table 1).

\begin{tabular}{|c|c|c|}
\hline Dimension of Flexibility & Type of Uncertainty & Strategic Goal \\
\hline Mix flexibility & $\begin{array}{c}\text { Market acceptance of different types of } \\
\text { products }\end{array}$ & Diverse product line \\
\hline Product innovation flexibility & Length of product life cycle & Product innovation \\
\hline Product modification flexibility & Specific characteristics of the product & Response to customer expectations \\
\hline Volume flexibility & Aggregate product demand & Market share \\
\hline Process routing flexibility & Inactive machines & Customer due date \\
\hline Material flexibility & Characteristics of materials & Strategic adaptability \\
\hline Response flexibility & Changes in the uncertainties mentioned &
\end{tabular}

Table 1. Manufacturing flexibility dimensions (Gerwin, 1993)

Information Technology implementation in the supply chain plays a crucial and strategic role in collaborative partnering as it enables integration of the information for improvements in products, quality, and flow of materials among others. It also leads to optimization of space availability, teamwork, improved productivity, and increased product and process flexibility (Stevenson \& Spring, 2007; Soroor et al., 2009). Most of these benefits are derived from adjustability in manufacturing programming, provision of materials, and planning of delivery deadlines (Jin et al., 2014).

This integration needs a high level of involvements from all areas of the firm and partners within the added value chain (Liu, Shah \& Schroeder, 2012). Once the products are manufactured, subsequent functions involving distribution up to the end customer must ensure that delivery occurs within the terms 
and deadlines agreed upon. To fulfil this multidisciplinary effort, the firm must assume a level of uncertainty derived from its internal (mistakes, delays, defective materials, etc.) as well as external environment (demand and/or supply variability), which can have a direct impact on the flexibility level of the entire production system. It is important to consider the multiple relationships of interdependence both within and outside the firm, as uncertainties have the potential to expand throughout the chain (De Toni \& Tonchia, 2005; Handfield \& Nichols, 2002; Sawhney, 2006).

Firms can thus face uncertainty and variability based on the strategic orientation of flexibility:

- Reactive orientation: in this case, developing flexibility involves the ability to fit production to market demand with the least time and cost (Beach et al., 2000; Collins, Cordon \& Julien, 1998; Gerwin, 1993; Gupta \& Somers, 1996; Iravani, Van Oyen \& Sims, 2005; Mackenzie, 1998; Milliken, 1987; Schmenner \& Tatikonda, 2005; Swamidas \& Newell, 1987).

- Proactive orientation: flexibility seeks to generate competitive advantages by developing abilities that enable the firm to focus products to a market niche, adapt the product to the consumers requirements, or increasing innovativeness (Bolwijn \& Kumpe, 1990; Sawhney, 2006).

Stevenson and Spring (2007) structure 21 dimensions of flexibility in a hierarchy with 4 levels: operations, tactical, strategic, and supply chain levels. The first three levels are bound to manufacturing flexibility while supply chain covers a wider aspect of flexibility. From these dimensions, Zhang et al. (2003) consider machine, labor, routing, and material handling flexibility (operations flexibility) as competences and mix and volume flexibility as capabilities (tactical flexibility). For these authors, the competences impact performance through flexibility as shown in Table 2. From the perspective of competitiveness, volume and mix flexibility are considered crucial as capabilities referred to short term reaction to variability in order volumes while the rest of the dimensions are more related to long term counteraction as they generate abilities for adapting resources that previously required high levels of financial compromise (Cox, 1989; New, 1996; Oke, 2003; Zhang et al., 2003).

\section{Competences}

- Machine flexibility: ability of a part of the team to perform different operations efficiently and economically.

- Labor flexibility: ability of labour to perform a wide range of functions efficiently and economically.

- Material handling flexibility: ability to transport different parts among various work centers through multiple routes efficiently and economically.

- Routing flexibility: ability to process a set of parts using multiple routes efficiently and effectively.

\section{Capabilities}

- Product modification flexibility

- Mix flexibility: ability to handle a wide range of products efficiently and economically, given a certain volume.

- Volume flexibility: ability to increase or decrease the aggregate production level 
Flexibility as a competitive priority concerns operations strategy processes to build capabilities for anticipating the firm's current needs (Hayes \& Wheelwright, 1984; Urgal-González \& García-Vázquez, 2007) through the practice known as production proactivity (Ward, Leong \& Boyer, 1994; Chang, Lin, Chen \& Huang, 2005). This practice generates commitment to continuous technological advances, development of multidisciplinary teams, and integration of production into the functions of marketing and design. Operations, machinery, process routes, tasks, product, work, material, program, and expansion of production influence as well the generation of new strategic capabilities. Managers need to find the right mix in the operations flexibility dimensions according to the strategic goals. Chang et al. (2005) found that dimensions that affect internal efficiency, such as Flexibility of Machines, Flexibility of Components, Flexibility of Material, or Routing Flexibility affect positively efficiency in fulfilling customers demand, while dimensions such as mix and volume flexibility have a positive impact when dealing with uncertainties in the environment and demand variations (Chang et al., 2005). Hence, from the strategic point of view, the flexibility dimensions have a direct impact on operational performance (Bustinza-Sánchez, Molina-Fernandez \& Arias-Aranda, 2010).

Based on the foregoing theoretical review and following the framework provided by Zhang et al. (2003) of flexible manufacturing competencies and capabilities the present study intends to analyze the distinct relationships between It integration, the different dimensions of flexibility and performance to establish the following hypothesis:

H1a. An increase in the degree of IT integration increases machine flexibility.

H1b. An increase in the degree of IT integration increases labour flexibility.

H1c. An increase in the degree of IT integration increases material handling flexibility.

H1d. An increase in the degree of IT integration increases routing flexibility.

H1e. An increase in the degree of IT integration increases volume flexibility.

H1f. An increase in the degree of IT integration increases material mix flexibility.

This hypothesis is subdivided in 12 sub-hypotheses, one for every relationship between the main constructs and the different dimensions of operations flexibility as shown is Figure 1.

H2a. Machine flexibility is positively related to performance.

H2b. Labour flexibility is positively related to performance.

H2c. Material handling flexibility is positively related to performance.

H2d. Routing flexibility is positively related to performance.

H2e. Volume flexibility is positively related to performance.

H2f. Mix flexibility is positively related to performance. 


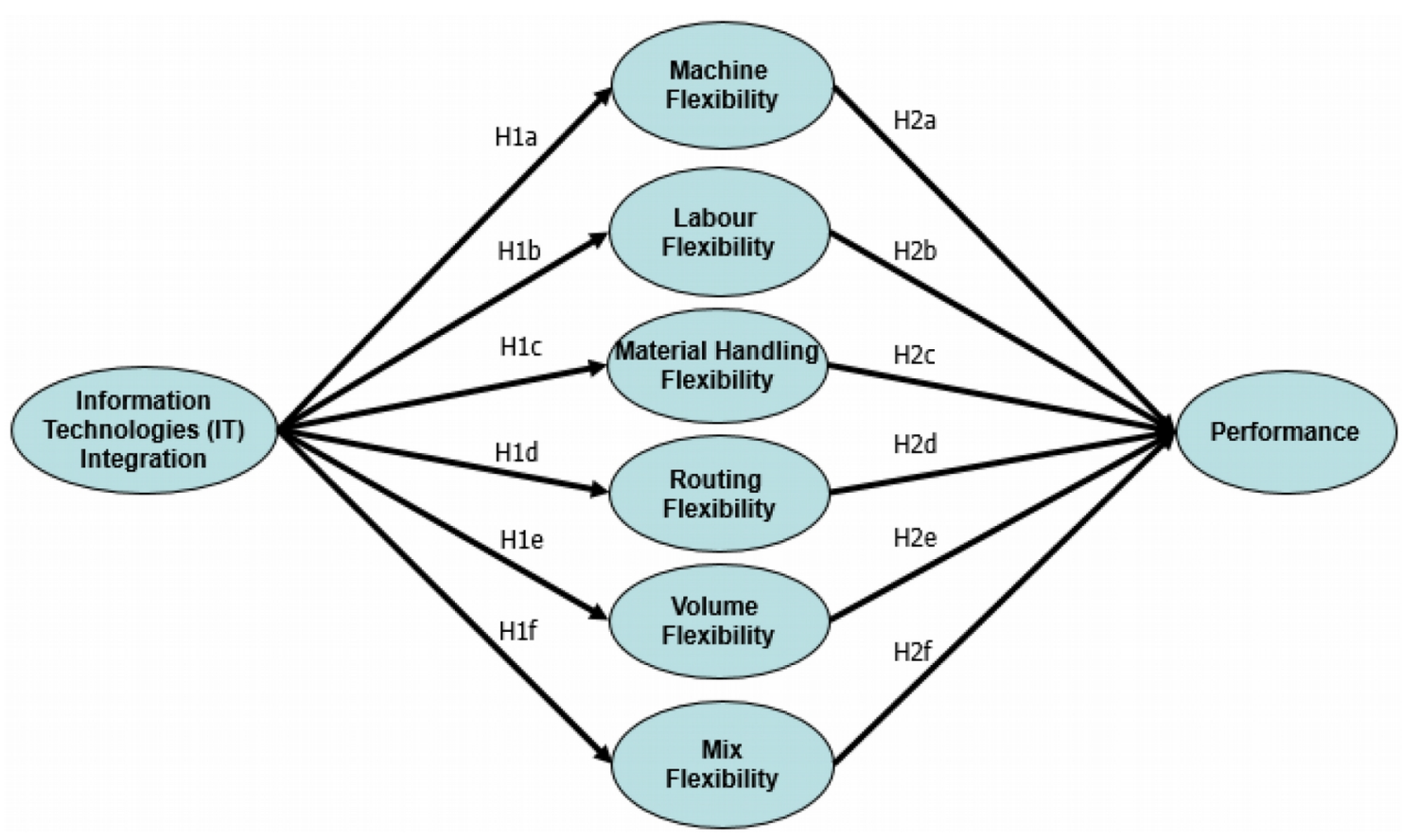

Figure 1. Conceptual Model

\section{Methodology}

\subsection{Data Samples and Scales}

This study is based on a sample drawn from a set of manufacturing firms from the SABI database. The data collection process was based entirely on a telephone survey. A pilot test with ten firms was performed in the initial questionnaire in order to ensure a clear understanding of the questions and items included. During the next stage, production, quality and operations managers were interviewed and informed about the research. 1,032 firms were contacted obtaining 201 valid surveys with a response rate of 19.47 per cent, and an estimated sampling error of 5.47 per cent. Next we analyze the possible non-respondent bias. For this purpose, we run t-tests to observe the difference between early and late respondents in the variables sales volume, number of employees and industry. Results did not indicate any significant difference between both groups. Thus, both groups of respondents do not introduce significant bias into the results of this research. Finally, we also analyze the common method variance (CMV). For this purpose, we performed a confirmatory factor analysis (CFA) to Harman's one factor test (Podsakoff, Mackenzie, Lee \& Podsakoff, 2003). If all the items are significantly related to a unique factor, CMV represents a problem. Our results show that a one-factor model has a poor fit with the data $($ RMSEA $=0.144 ; \mathrm{CFI}=0.393 ; \mathrm{NFI}=0.401)$ and consequently $\mathrm{CMV}$ is not a problem for our analyses.

Referring to the sample description, 24.38 per cent of the final sample reported annual revenues of 2 million Euros or less, 51.24 per cent reported annual revenues between 2 and 10 million Euros, while the 
rest 24.38 per cent reported revenues over 10 million Euros. Regarding the number of employees 73.13 per cent reported fewer than 50 employees, 19.40 per cent reported 51 to 250 employees, and 7.46 per cent reported 251 or more employees as shown in Table 3. The firms in the sample perform activities in different sectors such as agri-food manufacturing (fruit, vegetables, meat, etc.); technology components manufacturing (electronic, computers); and textile and footwear manufacturing (CNAE code 2009: 10 - food industry, 11 - Beverage manufacturing, 13 - Textile industry, 14 - Apparel manufacturing, 15 - Leather and footwear industry) (see Figure 2).

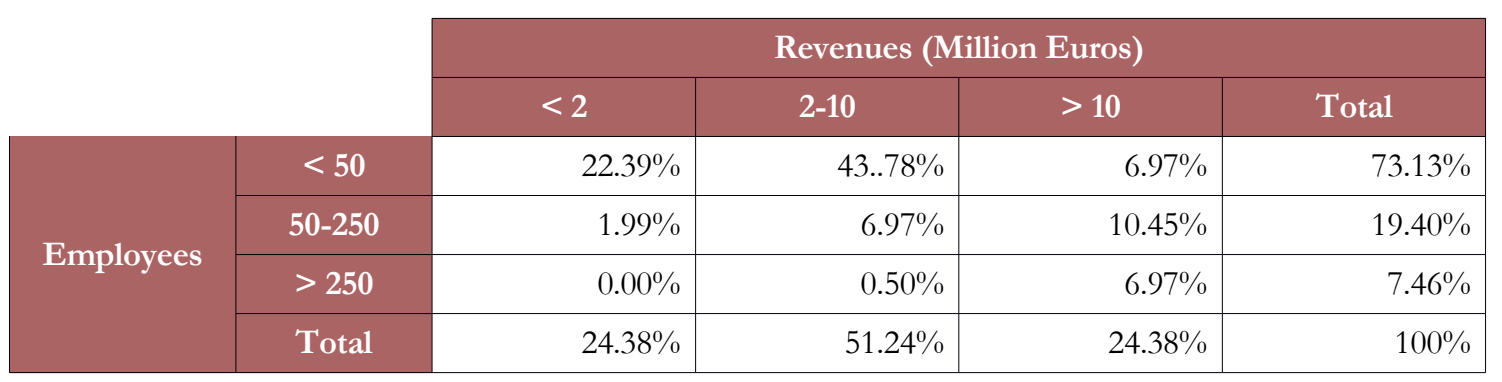

Table 3. Sample description (Revenue and Employees)

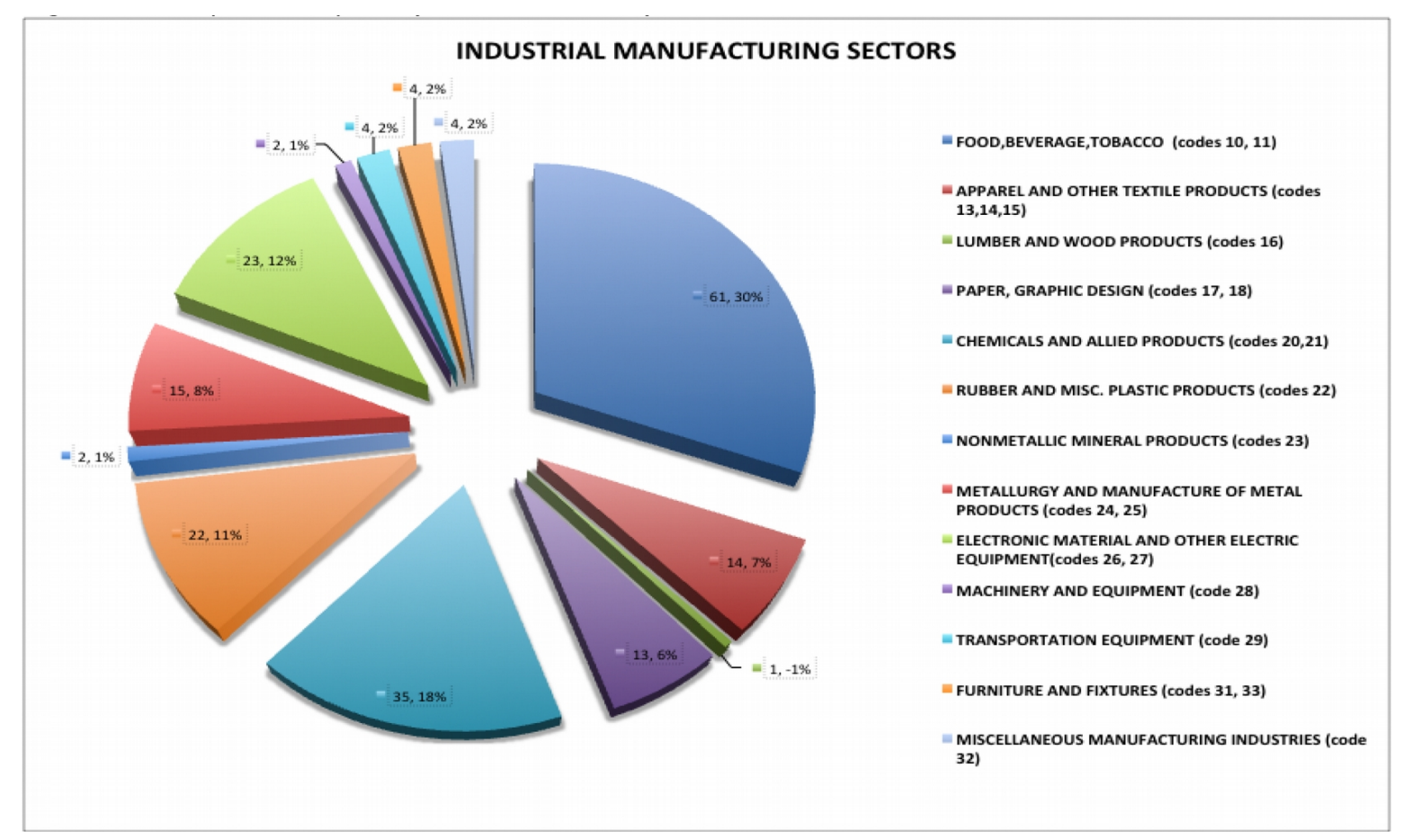

Figure 2. Sample description (industrial sectors)

The scale developed by Chan, Huff, Barclay \& Copeland (1997) and subsequently by Byrd, Lewis \& Bryan (2006) was included in the final questionnaire in order to measure IT integration into business strategy. This scale measures the orientation of existing IT within the business strategy. The items 
included in this study focus specifically on analyzing two strategic dimensions of IT: aggressive and defensive IT orientation within the business strategy. The different items of the questionnaire evaluate the degree of agreement with the integration of existing IT in the firm according to such strategic dimensions. For measuring operations flexibility, the scales validated by Zhang et al. (2003) regarding flexibility competences were used. The study considers the dimensions of machine, labour, material handling, routing, volume and mix flexibility (Tu, Vonderembse, Ragu-Nathan \& Sharkey, 2006; Zhang et al., 2006; Charles, Lauras \& Van Wassenhove, 2010). Operations performance has been measured adapting the scales of Abernethy and Lillis (1995). Different measurements of performance have been included in the research based on efficiency of the system as well as customer satisfaction by benchmarking firms performance with competitors. All items shown in Table 5 are measured through a 7 -point Likert scale, in which 1 indicates completely disagree and 7 completely agree on every statement.

\section{Results}

\subsection{Scale Validation Process}

Prior to confirming empirically the validity of the hypotheses and the scales validation, we include the descriptive statistics of observed variables (see table 4). . Next, the validation process was divided into two stages. First, we performed an explanatory factor analysis that enabled us to confirm the one-dimensionality of each scale. Second, we observed the scales' internal consistency by calculating the Cronbach's Alpha. In all cases, the resulting scales showed values higher than the recommended minimum of 0.7 (Nunnally \& Bernstein, 1978), guaranteeing internal consistency (see Table 5). To calculate one-dimensionality and internal consistency, we used SPSS 22.0 software.

The next step in the validation process was to perform a confirmatory factor analysis to enable analysis of the scales' validity. To achieve this, we used EQS 6.2 software. The conditions for validity require that the factor loadings be significant $(\mathrm{t}$-value $>1.96, \mathrm{p}<0.05)$ and have individual reliability $\left(\mathrm{R}^{2}\right)$ higher than 0.4 (Hair, 2010; Kim, Kumar \& Kumar, 2012). As a result of this process, some items were eliminated from the scales. Table 5 includes the items remaining after the validation process, which are shown to fulfil the requirements to guarantee validity of the scales. Table 5 also includes the descriptive statistics of the items used. Following Szulanski (1996), we also analyzed the discriminant validity of the scales. The results showed that each construct is significantly different. Finally, we observed the composite reliability of scales that exceeded the recommended value (0.7), and the average variance extracted (AVE) that exceeded the accepted value (0.5). After the full validation process, the resulting items were used in the subsequent analysis. 


\begin{tabular}{|c|c|c|c|c|c|c|c|c|c|c|}
\hline Variable & Mean & $\mathrm{SD}$ & \multicolumn{8}{|c|}{ Correlations } \\
\hline IT Integration & 35.419 & .85622 & 1 & & & & & & & \\
\hline Machine Flexibility & 32.264 & 104.340 & $.186^{* *}$ & 1 & & & & & & \\
\hline Labour Flexibility & 38.915 & .73817 & $.286^{* *}$ & $.263^{* *}$ & 1 & & & & & \\
\hline $\begin{array}{l}\text { Material Handling } \\
\text { Flexibility }\end{array}$ & 38.313 & .93122 & $.292^{* *}$ & $.279 * *$ & $.316^{* *}$ & 1 & & & & \\
\hline Routing Flexibility & 32.215 & 101.584 & $.338^{* *}$ & $.443^{* *}$ & $.275^{* *}$ & $.450 * *$ & 1 & & & \\
\hline Volume Flexibility & 39.450 & .80469 & $.224 * *$ & $.223^{* *}$ & $.286^{* *}$ & $.223^{* *}$ & $.320 * *$ & 1 & & \\
\hline Mix Flexibility & 37.123 & 109.065 & $.282^{* *}$ & .118 & $.153 *$ & $.334 * *$ & $.314^{* *}$ & $.202^{* *}$ & 1 & \\
\hline Performance & 35.609 & .71857 & $.284 * *$ & $.191^{* *}$ & $.283^{* *}$ & $.243^{* *}$ & $.156^{*}$ & $.206^{* *}$ & $.153 *$ & 1 \\
\hline
\end{tabular}

${ }^{*}$ Correlation is significant at the 0.05 level; ${ }^{* *}$ Correlation is significant at the 0.01 level.

Table 4. Descriptive statistics and reliability analysis

\begin{tabular}{|c|c|c|c|c|c|c|c|c|}
\hline Items & Code & $\begin{array}{c}\text { Mea } \\
\mathrm{n}\end{array}$ & S.D. & $\begin{array}{l}\text { Standardized } \\
\text { factor loadings } \\
\text { and } t-v a l u e s \\
\left(>0.4^{a} ; t>1.96^{a}\right)\end{array}$ & $\begin{array}{c}\mathrm{R} 2 \\
(>0.5 \mathrm{a}) \\
1\end{array}$ & $\begin{array}{l}\text { Cronbach' } \\
\text { s Alpha } \\
\left(>0.7^{\mathrm{b}}\right)\end{array}$ & $\begin{array}{l}\text { Composite } \\
\text { reliability } \\
(>0.7)\end{array}$ & $\begin{array}{l}\text { Average } \\
\text { variance } \\
\text { extracted } \\
(>0.5)\end{array}$ \\
\hline $\begin{array}{l}\text { Information } \\
\text { Technology } \\
\text { Integration }\end{array}$ & & & & & & .898 & .900 & .584 \\
\hline $\begin{array}{l}\text { The IT's we use help us } \\
\text { to be or become one of } \\
\text { the leading firms in our } \\
\text { market. }\end{array}$ & ITI1 & 3.335 & .9914 & $.660(\mathrm{t}=10.03)$ & .436 & & & \\
\hline $\begin{array}{l}\text { The IT's we use help us } \\
\text { to be on the cutting } \\
\text { edge with respect to our } \\
\text { competition. }\end{array}$ & ITI2 & 3.48 & 10.294 & $.718(\mathrm{t}=11.42)$ & .516 & & & \\
\hline $\begin{array}{l}\text { The IT's we use help us } \\
\text { to achieve market share. }\end{array}$ & $\begin{array}{c}\text { ITI3 } \\
\text { Eliminated }\end{array}$ & --- & --- & --- & --- & & & \\
\hline $\begin{array}{l}\text { The IT's we use help us } \\
\text { to develop strong ties to } \\
\text { our main customers. }\end{array}$ & ITI4 & 3.698 & 10.581 & $.839(\mathrm{t}=15.92)$ & .705 & & & \\
\hline $\begin{array}{l}\text { The IT's we use help us } \\
\text { to develop strong ties to } \\
\text { our main suppliers. }\end{array}$ & ITI5 & 3.678 & 10.085 & $.826(\mathrm{t}=14.73)$ & .683 & & & \\
\hline $\begin{array}{l}\text { The IT's we use help us } \\
\text { to connect strongly to } \\
\text { the market in general. }\end{array}$ & ITI6 & 3.518 & .9892 & $.834(\mathrm{t}=15.30)$ & .696 & & & \\
\hline Machine Flexibility & & & & & & .772 & .775 & .537 \\
\hline $\begin{array}{l}\text { Our machinery can be } \\
\text { installed/configured } \\
\text { rapidly. }\end{array}$ & MACH1 & 3.364 & 1.311 & $.683(\mathrm{t}=9.49)$ & .466 & & & \\
\hline $\begin{array}{l}\text { Any machine can } \\
\text { perform different types } \\
\text { of operations. }\end{array}$ & $\begin{array}{c}\text { MACH2 } \\
\text { Eliminated }\end{array}$ & --- & --- & --- & --- & & & \\
\hline $\begin{array}{l}\text { Any machine can use } \\
\text { different devices } \\
\text { effectively. }\end{array}$ & $\begin{array}{l}\text { MACH3 } \\
\text { Eliminated }\end{array}$ & --- & --- & --- & --- & & & \\
\hline
\end{tabular}




\begin{tabular}{|c|c|c|c|c|c|c|c|c|}
\hline Items & Code & $\begin{array}{c}\text { Mea } \\
\mathrm{n}\end{array}$ & S.D. & $\begin{array}{l}\text { Standardized } \\
\text { factor loadings } \\
\text { and } t-v a l u e s \\
\left(>0.4^{\mathrm{a}} ; \mathrm{t}>1.96^{\mathrm{a}}\right)\end{array}$ & $\begin{array}{c}\mathrm{R} 2 \\
(>0.5 \mathrm{a}) \\
1\end{array}$ & $\begin{array}{l}\text { Cronbach' } \\
\text { s Alpha } \\
\left(>0.7^{\mathrm{b}}\right)\end{array}$ & $\begin{array}{l}\text { Composite } \\
\text { reliability } \\
(>0.7)\end{array}$ & $\begin{array}{l}\text { Average } \\
\text { variance } \\
\text { extracted } \\
(>0.5)\end{array}$ \\
\hline $\begin{array}{l}\text { Our machines often } \\
\text { become obsolete when } \\
\text { new operations are } \\
\text { introduced in the firm. }\end{array}$ & $\begin{array}{l}\text { MACH4 } \\
\text { Eliminated }\end{array}$ & --- & --- & --- & --- & & & \\
\hline $\begin{array}{l}\text { The devices on our } \\
\text { machines can be } \\
\text { changed rapidly. }\end{array}$ & MACH5 & 3.095 & 12.108 & $.682(\mathrm{t}=9.03)$ & .464 & & & \\
\hline $\begin{array}{l}\text { It is easy to } \\
\text { install/configure our } \\
\text { machinery. }\end{array}$ & MACH6 & 3.22 & 12.536 & $.826(\mathrm{t}=9.18)$ & .683 & & & \\
\hline Labor Flexibility & & & & & & .843 & .845 & .579 \\
\hline $\begin{array}{l}\text { Our workers can } \\
\text { perform different types } \\
\text { of operations efficiently. }\end{array}$ & LAB1 & 3.98 & .8483 & $.712(\mathrm{t}=8.57)$ & .507 & & & \\
\hline $\begin{array}{l}\text { Any worker is able to } \\
\text { work efficiently with } \\
\text { different devices. }\end{array}$ & LAB2 & 3.731 & .9314 & $.701(t=10.06)$ & .491 & & & \\
\hline $\begin{array}{l}\text { Our polyvalent } \\
\text { workers(qualified in } \\
\text { various fields) can } \\
\text { perform a large number } \\
\text { of tasks in the firm } \\
\text { efficiently. }\end{array}$ & LAB3 & 3.98 & .8829 & $.868(t=12.35)$ & .753 & & & \\
\hline $\begin{array}{l}\text { Our workers can/are } \\
\text { trained to work various } \\
\text { types of machines. }\end{array}$ & LAB4 & 3.874 & .9161 & $.752(\mathrm{t}=9.83)$ & .565 & & & \\
\hline $\begin{array}{l}\text { Our workers can easily } \\
\text { be transferred to other } \\
\text { departments or units in } \\
\text { the same firm. }\end{array}$ & $\begin{array}{c}\text { LAB5 } \\
\text { Eliminated }\end{array}$ & --- & --- & --- & --- & & & \\
\hline $\begin{array}{l}\text { Material Handling } \\
\text { Flexibility }\end{array}$ & & & & & & .867 & .868 & .688 \\
\hline $\begin{array}{l}\text { Our material handling } \\
\text { system enables us to } \\
\text { manipulate, move, } \\
\text { and/or transport } \\
\text { different kinds of } \\
\text { components. }\end{array}$ & MAT1 & 3.874 & 10.195 & $.843(t=12.48)$ & .711 & & & \\
\hline $\begin{array}{l}\text { Our material handling } \\
\text { system can work in } \\
\text { different processing } \\
\text { areas. }\end{array}$ & MAT2 & 3.821 & 10.361 & $.775(t=9.98)$ & .600 & & & \\
\hline $\begin{array}{l}\text { Our material handling } \\
\text { system can move } \\
\text { different kinds of } \\
\text { components through } \\
\text { our factory installations. }\end{array}$ & MAT3 & 3.799 & 10.862 & $.868(t=14.02)$ & .753 & & & \\
\hline $\begin{array}{l}\text { Our material handling } \\
\text { system enables us to } \\
\text { exchange/replace } \\
\text { components rapidly. }\end{array}$ & $\begin{array}{c}\text { MAT4 } \\
\text { Eliminated }\end{array}$ & --- & --- & --- & --- & & & \\
\hline
\end{tabular}




\begin{tabular}{|c|c|c|c|c|c|c|c|c|}
\hline Items & Code & $\begin{array}{c}\text { Mea } \\
\mathrm{n}\end{array}$ & S.D. & $\begin{array}{l}\text { Standardized } \\
\text { factor loadings } \\
\text { and t-values } \\
\left(>0.4^{\mathrm{a}} ; \mathrm{t}>1.96^{\mathrm{a}}\right)\end{array}$ & $\begin{array}{c}\mathbf{R} 2 \\
(>0.5 \mathrm{a}) \\
1\end{array}$ & $\begin{array}{l}\text { Cronbach' } \\
\text { s Alpha } \\
\left(>0.7^{\mathrm{b}}\right)\end{array}$ & $\begin{array}{l}\text { Composite } \\
\text { reliability } \\
(>0.7)\end{array}$ & $\begin{array}{l}\text { Average } \\
\text { variance } \\
\text { extracted } \\
(>0.5)\end{array}$ \\
\hline $\begin{array}{l}\text { The devices we use for } \\
\text { material handling can be } \\
\text { changed or replaced } \\
\text { rapidly. }\end{array}$ & $\begin{array}{c}\text { MAT5 } \\
\text { Eliminated }\end{array}$ & --- & --- & --- & --- & & & \\
\hline Routing Flexibility & & & & & & .825 & .828 & .618 \\
\hline $\begin{array}{l}\text { A typical part operation } \\
\text { can be routed to } \\
\text { different machines }\end{array}$ & $\begin{array}{l}\text { ROUT1 } \\
\text { Eliminated }\end{array}$ & --- & --- & --- & --- & & & \\
\hline $\begin{array}{l}\text { A typical part can use } \\
\text { many different routes }\end{array}$ & $\begin{array}{c}\text { ROUT2 } \\
\text { Eliminated }\end{array}$ & --- & --- & --- & --- & & & \\
\hline $\begin{array}{l}\text { The system has } \\
\text { alternative routes in case } \\
\text { machines break down }\end{array}$ & ROUT3 & 3.342 & 11.535 & $.682(\mathrm{t}=8.25)$ & .466 & & & \\
\hline $\begin{array}{l}\text { The operating sequence } \\
\text { through which the parts } \\
\text { flow can be changed }\end{array}$ & ROUT4 & 3.091 & 12.132 & $.839(\mathrm{t}=12.54)$ & .703 & & & \\
\hline $\begin{array}{l}\text { Machine visitation } \\
\text { sequence can be } \\
\text { changed or replaced } \\
\text { quickly }\end{array}$ & $\begin{array}{l}\text { ROUT5 } \\
\text { Eliminated }\end{array}$ & --- & --- & --- & --- & & & \\
\hline $\begin{array}{l}\text { Route changeovers are } \\
\text { easy }\end{array}$ & ROUT6 & 3.231 & 11.734 & $.828(t=13.78)$ & .686 & & & \\
\hline Volume Flexibility & & & & & & .884 & .885 & .719 \\
\hline $\begin{array}{l}\text { We can function } \\
\text { efficiently at different } \\
\text { production levels. }\end{array}$ & $\begin{array}{c}\text { VOL1 } \\
\text { Eliminated }\end{array}$ & --- & --- & --- & --- & & & \\
\hline $\begin{array}{l}\text { We can work profitably } \\
\text { with different } \\
\text { production volumes. }\end{array}$ & $\begin{array}{l}\text { VOL2 } \\
\text { Eliminated }\end{array}$ & --- & --- & --- & --- & & & \\
\hline $\begin{array}{l}\text { We can produce } \\
\text { different lot sizes } \\
\text { efficiently. }\end{array}$ & $\begin{array}{c}\text { VOL3 } \\
\text { Eliminated }\end{array}$ & --- & --- & --- & --- & & & \\
\hline $\begin{array}{l}\text { We can change our } \\
\text { production volume } \\
\text { rapidly. }\end{array}$ & VOL4 & 3.96 & .8593 & $.800(\mathrm{t}=12.17)$ & .640 & & & \\
\hline $\begin{array}{l}\text { We can change total } \\
\text { production from one } \\
\text { period to another. }\end{array}$ & VOL5 & 3.975 & .9189 & $.893(t=17.37)$ & .797 & & & \\
\hline $\begin{array}{l}\text { We can easily change } \\
\text { the production volume } \\
\text { of a manufacturing } \\
\text { process. }\end{array}$ & VOL6 & 3.9 & .9 & $.850(\mathrm{t}=15.22)$ & .722 & & & \\
\hline Mix Flexibility & & & & & & .883 & .885 & .721 \\
\hline $\begin{array}{l}\text { We can produce a wide } \\
\text { variety of products in } \\
\text { our plants }\end{array}$ & MIX1 & 3.831 & 12.733 & $.895(t=7.30)$ & .802 & & & \\
\hline $\begin{array}{l}\text { We can produce } \\
\text { different product types } \\
\text { without major } \\
\text { changeover }\end{array}$ & MIX2 & 3.791 & 11.559 & $.887(t=7.74)$ & .788 & & & \\
\hline
\end{tabular}




\begin{tabular}{|c|c|c|c|c|c|c|c|c|}
\hline Items & Code & $\begin{array}{c}\text { Mea } \\
\mathrm{n}\end{array}$ & S.D. & $\begin{array}{l}\text { Standardized } \\
\text { factor loadings } \\
\text { and t-values } \\
\left(>0.4^{\mathrm{a}} ; \mathrm{t}>1.96^{\mathrm{a}}\right)\end{array}$ & $\begin{array}{c}\mathbf{R} 2 \\
(>0.5 a) \\
1\end{array}$ & $\begin{array}{l}\text { Cronbach' } \\
\text { s Alpha } \\
\left(>0.7^{\mathrm{b}}\right)\end{array}$ & $\begin{array}{l}\text { Composite } \\
\text { reliability } \\
(>0.7)\end{array}$ & $\begin{array}{l}\text { Average } \\
\text { variance } \\
\text { extracted } \\
(>0.5)\end{array}$ \\
\hline $\begin{array}{l}\text { We can build different } \\
\text { products in the same } \\
\text { plants at the same time }\end{array}$ & $\begin{array}{c}\text { MIX3 } \\
\text { Eliminated }\end{array}$ & --- & --- & --- & --- & & & \\
\hline $\begin{array}{l}\text { We can produce, } \\
\text { simultaneously or } \\
\text { periodically, multiple } \\
\text { products in a steady- } \\
\text { state operating mode }\end{array}$ & MIX4 & 3.515 & 12.030 & $.760(\mathrm{t}=5.35)$ & .578 & & & \\
\hline $\begin{array}{l}\text { We can vary product } \\
\text { combinations from one } \\
\text { period to the next }\end{array}$ & $\begin{array}{l}\text { MIX5 } \\
\text { Eliminated }\end{array}$ & --- & --- & --- & --- & & & \\
\hline $\begin{array}{l}\text { We can changeover } \\
\text { quickly from one } \\
\text { product to another }\end{array}$ & $\begin{array}{c}\text { MIX6 } \\
\text { Eliminated }\end{array}$ & --- & --- & --- & --- & & & \\
\hline Performance & & & & & & .848 & .848 & .584 \\
\hline $\begin{array}{l}\text { Evolution of worker } \\
\text { efficiency level }\end{array}$ & PERF1 & 3.569 & .8145 & $.703(\mathrm{t}=7.69)$ & .495 & & & \\
\hline $\begin{array}{l}\text { Percentage use of } \\
\text { production capacity }\end{array}$ & PERF2 & 3.514 & .8666 & $.808(\mathrm{t}=7.90)$ & .653 & & & \\
\hline $\begin{array}{l}\text { Evaluation of ability to } \\
\text { vary, adapt, or } \\
\text { personalize product } \\
\text { characteristics }\end{array}$ & PERF3 & 3.646 & .8776 & $.765(\mathrm{t}=8.66)$ & .585 & & & \\
\hline $\begin{array}{l}\text { Percentage of } \\
\text { production vs. leisure } \\
\text { time }\end{array}$ & PERF4 & 3.515 & .9061 & $.779(\mathrm{t}=9.44)$ & .607 & & & \\
\hline
\end{tabular}

a Hulland (1999); b Nunnally (1978)

Table 5. Scale items and validation

\subsection{Structural Equations Model (SEM)}

To contrast the hypotheses, we performed SEM using EQS 6.2 software. Figure 3 includes the results obtained in the SEM. First, if we refer to the set of hypotheses that relate integration to information technologies and the different dimensions of flexibility, the results show that all relationships are positive and significant (machine $\lambda=.351^{* * *} ; \mathrm{t}=3.408$; labour $\lambda=.431^{* * *} ; \mathrm{t}=4.978$; material handling $\lambda=.552^{* * *}$; $\mathrm{t}=5.255$, routing $\lambda=.644^{* * *} ; \mathrm{t}=5.296$; volume $\lambda=.379 * * * ; \mathrm{t}=3.865$ and mix $\lambda=.455^{* * *} ; \mathrm{t}=4.531$ ). This result enables us to accept Hypothesis 1. For the group of hypotheses relating the dimensions of flexibility to performance, we see that only four of the six dimensions show a positive and significant relationship (machine $\lambda=.558^{*} ; \mathrm{t}=1.700$; labour $\lambda=.989^{* * *}$; $\mathrm{t}=2.742$; material handling $\lambda=.580^{* *} ; \mathrm{t}=1.990$ and volume $\lambda=.504 * * ; \mathrm{t}=2.012$ ). We can thus affirm that Hypothesis 2 is partially confirmed. Finally, Table 6 includes the value of the fit indexes associated with the structural model. As can be seen, all 
indexes show values above the recommended minimums, indicating that the model shows good fit for interpretation.

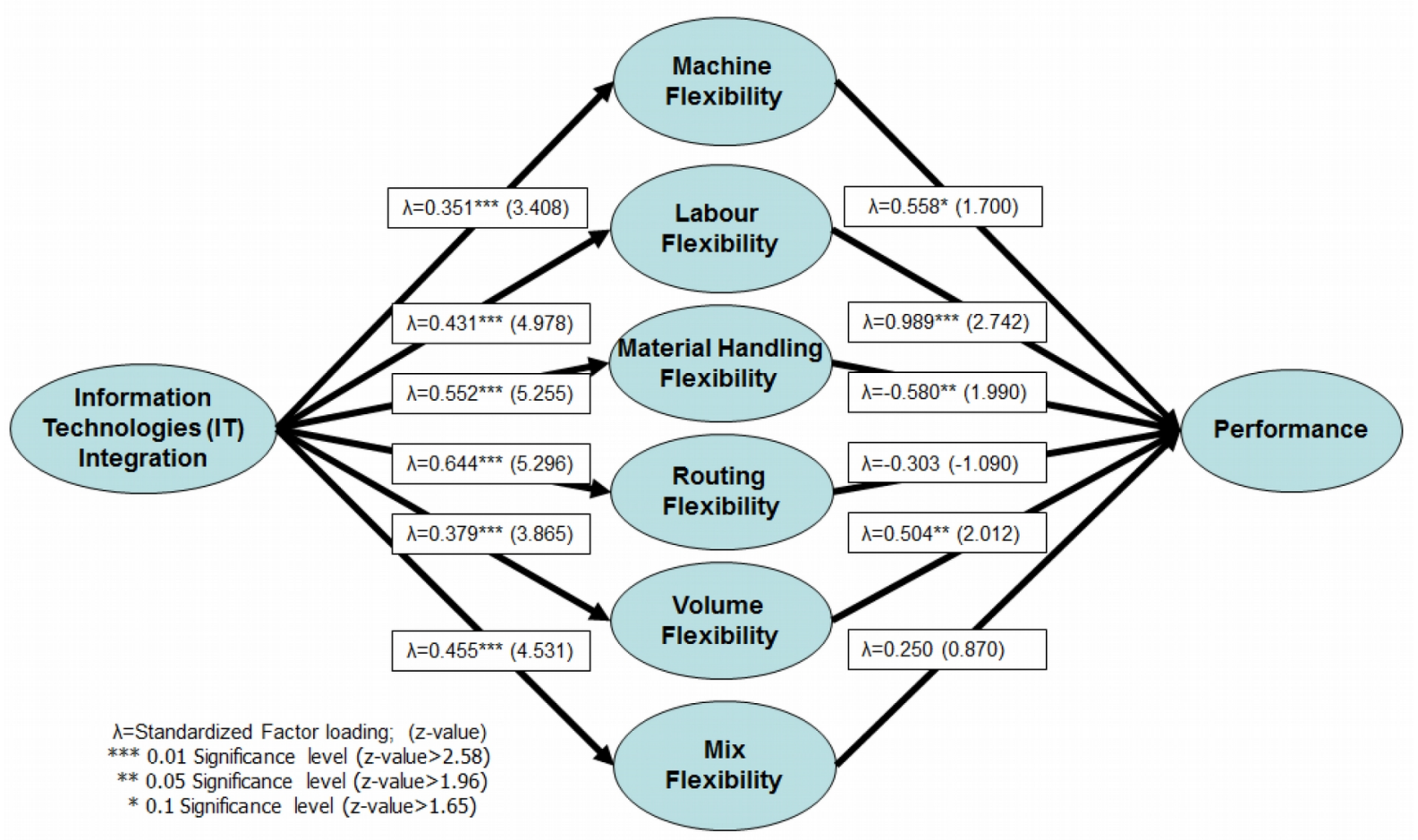

Figure 3. Relationships of the model

\begin{tabular}{|l|r|r|}
\hline Fit Index & Model & Acceptance levels \\
\hline Chi-square & 569.966 & \\
\hline Degrees of freedom & 328 & $<3.0^{\mathrm{b}}$ \\
\hline Normed Chi-square $\chi^{2} / \mathrm{df}$ & 1.737 & $<0.08^{\mathrm{b}}$ \\
\hline $\begin{array}{l}\text { Root Mean Square Error of } \\
\text { Approximation (RMSEA) }\end{array}$ & .061 & $>0.9^{\mathrm{c}}$ \\
\hline Comparative Fit Index (CFI) & .919 & $>0.9^{\mathrm{c}}$ \\
\hline Bollen's Fit Index (IFI) & .920 & $>0.5^{\mathrm{c}}$ \\
\hline GFI Fit Index & .831 & $>0.5^{\mathrm{c}}$ \\
\hline AGFI Fit Index & .791 & ${ }^{\mathrm{c}}$ \\
\hline
\end{tabular}

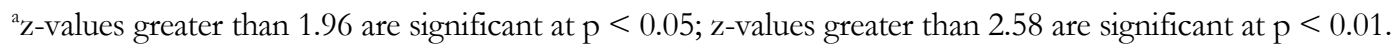

${ }^{\mathrm{b}}$ Hair, Tatham,, Anderson and Black (2006) and Byrne (1998); 'Byrne (1998).

Table 6. Structural Equation Modelling 


\section{Conclusions, Limitations and Future Lines of Research}

The main goal of this study is to develop a deeper understanding of the relationship between IT integration and performance through operations flexibility beyond those suggested by previous studies. Results prove a complex set of relationships in manufacturing firms which provides important implications for academics and managerial practice. First, based on the different dimensions of operations flexibility, this study uncovers how IT implementation impacts operational performance. This finding opens new research opportunities to analyze such impact to different environmental conditions. In future studies, additional perspectives under a contingency analysis can even clarify possible hidden aspects in this relationship. At this point, practitioners can have a better understanding on how IT implementation affects the different dimensions that configure the operations flexibility.

Second, a model of analysis of the relationships among IT implementation, flexibility and performance has been developed based on the classical manufacturing flexibility frameworks. This research analyzes these critical constructs though the use of empirical methods within a field-based setting. Some flexibility dimensions show no significant impact in performance (routing and mix flexibility). This is consistent with the fact that these flexibility dimensions act as variability absorbers within the manufacturing process. Routing flexibility is a competence that decreases the job flow pattern from a random job shop to a flow shop (Hitoshi \& Mitsuyoshi, 1999). Hence, when the production system is balanced, the impact of routing flexibility on performance may not be significant when variability is small. Regarding mix flexibility, it involves the capability to adjust quickly to changes in the demand. It affects performance when there is a large need for product variety. Hence, in multisectorial studies, the effect of mix flexibility on performance can be affected according to different product variability levels in different industries. In addition, current flexible technologies decrease the possibilities for mix flexibility improvements on operational performance as found by Karuppan and Kepes (2006). Therefore, future studies can focus on determining further internal and environmental factors that affect operations flexibility according to specific sector characteristics. These findings can improve practitioners decision process when choosing which combinations of flexibility dimensions fit better with strategic priorities, especially when dealing with financial options of IT investments and equipment.

Third, this research proves a significant positive and direct effect of IT implementation on operations performance. Results show not only the links between IT implementation and operations performance, but also the magnitude of every impact. Notwithstanding, it is necessary to be cautious when generalizing these findings as service firms were not part of the sample even when statistical results prove robustness suggesting that the findings are quite reliable. Further, our model considers IT integration as the degree of alignment that existing technology resources in a firm have with the business strategy, in terms of importance and support for this strategy. This integration seeks to generate value such as leveraging of IT 
investment, an idea also consistent with Byrd et al. (2006). The strategic role of IT is oriented to improving information flow and real-time coordination with suppliers that facilitates effective planning of production and provision of materials. When integrated into decision making, this information enables a faster evaluation of the firm's current level of flexibility to prioritize its resources, and identify resources leading to improve operations processes. This information will enable better integration with customers, allowing the firm to optimize deadlines and better adapt products to customer needs. Future sectorial analysis could provide more specific results considering as well service industries.

\section{References}

Abernethy, M.A., \& Lillis, A.M. (1995). The impact of manufacturing flexibility on management control system design. Accounting, Organizations and Society, 20(4), 241-258. http://dx.doi.org/10.1016/03613682(94)E0014-L

Ageron, B., Gunasekaran, A., \& Spalanzani, A. (2013). IS/IT as supplier selection criterion for upstream value chain. Industrial Management \& Data Systems, 113(3), 443-460.

http://dx.doi.org/10.1108/02635571311312703

Arias-Aranda, D. (2003). Service operations strategy, flexibility and performance in engineering consulting firms. International Journal of Operations \& Production Management, 23(11), 1401-1421. http://dx.doi.org/10.1108/01443570310501907

Avittathur, B., \& Swamidass, P. (2007). Matching plant flexibility and supplier flexibility: lessons from small suppliers of US manufacturing plants in India. Journal of Operations Management, 25(3), 717-735. http://dx.doi.org/10.1016/j.jom.2006.05.015

Barney, J. (1991). Firm resources and sustained competitive advantage. Journal of Management, 17(1), 99-120. http://dx.doi.org/10.1177/014920639101700108

Baykasoglu, A., \& Özbakir, L. (2008). Analysing the effect of flexibility on manufacturing systems performance. Journal of Manufacturing Technology Management, 19(2), 172-193.

http://dx.doi.org/10.1108/17410380810847909

Beach, R., Muhlemann, A., Price, D., Paterson, A., \& Sharp, J.A. (2000). A review of manufacturing flexibility. European Journal of Operational Research, 122(1), 41-57. http://dx.doi.org/10.1016/S0377$2217(99) 00062-4$ 
Bhatt, G.D., Grover, V., \& Grover, V. (2005). Types of information technology capabilities and their role in competitive advantage: an empirical study. Journal of Management Information Systems, 22(2), 253-277.

Bolwijn, P.T., \& Kumpe, T. (1990). Manufacturing in the 1990s: productivity, flexibility and innovation. Long Range Planning, 23(4), 44-57. http://dx.doi.org/10.1016/0024-6301(90)90151-S

Bustinza-Sánchez, O.F., Molina-Fernández, L.M., \& Arias-Aranda, D. (2010). Organizational learning and performance: Relationship between the dynamic and the operational capabilities of the firm. Journal of Business Management, 4(18), 4067-4078.

Byrd, T.A., Lewis, B.R., \& Bryan, R.W. (2006). The leveraging influence of strategic alignment on IT investment: an empirical examination. Information \& Management, 43(3), 308-321. http://dx.doi.org/10.1016/j.im.2005.07.002

Byrne, B.M. (1998). Structural Equation Modeling with LISREL, PRELIS, and SIMPLIS: Basis Concepts, Application, and Programming. Mahwah, New Jersey: Lawrence Erlbaum.

Chan, H., \& Chan, F. (2009). Effect of information sharing in supply chains with flexibility. International Journal of Production Research, 47(1), 213-232. http://dx.doi.org/10.1080/00207540600767764

Chan, Y.E., Huff, S.L., Barclay, D.W., \& Copeland, D.G. (1997). Business strategic orientation, information systems strategic orientation, and strategic alignment. Information Systems Research, 8(2), 125-150. http://dx.doi.org/10.1287/isre.8.2.125

Chang, S., Lin, R., Chen, J., \& Huang, L. (2005). Manufacturing flexibility and manufacturing proactiveness: Empirical evidence from the motherboard industry. Industrial Management and Data Systems, 105(8), 1115-1132. http://dx.doi.org/10.1108/02635570510624482

Charles, A., Lauras, M., \& Van Wassenhove, L. (2010). A model to define and assess the agility of supply chains: building on humanitarian experience. International Journal of Physical Distribution \& Logistics Management, 40(8/9), 722-741. http://dx.doi.org/10.1108/09600031011079355

Chwelos, P., Benbasat, I., \& Dexter, A.S. (2001). Research report: empirical test of an EDI adoption model. Information Systems Research, 12(3), 304-321. http://dx.doi.org/10.1287/isre.12.3.304.9708

Collins, R.S., Cordon, C., \& Julien, D. (1998). An empirical test of the rigid flexibility model. Journal of Operations Management, 16(2), 133-146. http://dx.doi.org/10.1016/S0272-6963(97)00033-8

Cox, T. (1989). Toward the measurement of manufacturing flexibility. Production and Inventory Management Journal, 30(1), 68-72.

Das, A., Narasimhan, R., \& Talluri, S. (2006). Supplier integration-finding an optimal configuration. Journal of Operations Management, 24(5), 563-582. http://dx.doi.org/10.1016/j.jom.2005.09.003 
De Toni, A., \& Tonchia, S. (1998). Manufacturing flexibility: A literature review. International Journal of Production Research, 36(6), 1587-1617. http://dx.doi.org/10.1080/002075498193183

De Toni, A. \& Tonchia, S.(2005). Definitions and linkages between operational and strategic flexibilities. Omega, 33(6), 525-540. http://dx.doi.org/10.1016/j.omega.2004.07.014

Flynn, B.B., Huo, B., \& Zhao, X. (2010). The impact of supply chain integration on performance: a contingency and configuration approach. Journal of Operations Management, 28(1), 58-71. http://dx.doi.org/10.1016/j.jom.2009.06.001

Francas, D., Kremer, M., Minner, S., \& Friese, M. (2009). Strategic process flexibility under lifecycle demand. International Journal of Production Economics, 121(2), 427-440.

http://dx.doi.org/10.1016/j.ijpe.2006.12.062

Frohlich, M.T., \& Westbrook, R. (2001). Arcs of integration: an international study of supply chain strategies. Journal of Operations Management, 19(2), 185-200. http://dx.doi.org/10.1016/S0272-6963(00)00055-3

Gerwin, D. (1993).Manufacturing flexibility: a strategic perspective. Management Science, 39(4), 395-410. http://dx.doi.org/10.1287/mnsc.39.4.395

Giménez, C., van der Vaart, T., \& van Donk, D.P. (2012). Supply chain integration and performance: The moderating effect of supply complexity. International Journal of Operations \& Production Management, 32(5), 583-610. http://dx.doi.org/10.1108/01443571211226506

Gupta, Y.P., \& Somers, T.M. (1996). Business strategy, manufacturing flexibility, and organizational performance relationships: a path analysis approach. Production and Operations Management, 5(3), 204-233. http://dx.doi.org/10.1111/j.1937-5956.1996.tb00395.x

Hair, J.F. (2010). Multivariate data analysis Pearson College Division.

Hair, J.F., Tatham, R.L., Anderson, R.E., \& Black, W. (2006). Multivariate data analysis. Upper Saddle River, NJ.: Pearson Prentice Hall.

Handfield, R.B., \& Nichols, E.L. (2002). Supply chain redesign: Transforming supply chains into integrated value systems. FT Press.

Hayes, R.H., \& Wheelwright, S.C. (1984). Restoring our competitive edge: competing through manufacturing. New York, NY: John Wiley \& Sons. 
Hitt, L.M., \& Brynjolfsson, E. (1996). Productivity, business profitability, and consumer surplus: Three different measures of information technology value. MIS Quarterly, 20(2), 121-142. http://dx.doi.org/10.2307/249475

Hitoshi, T., \& Mitsuyoshi, H. (1999): A Comparison between machine flexibility and Routing flexibility. International Journal of Flexible manufacturing System, 11(1), 83-101. http://dx.doi.org/10.1023/A:1008096724273

Iravani, S.M., Van Oyen, M.P., \& Sims, K.T. (2005). Structural flexibility: a new perspective on the design of manufacturing and service operations. Management Science, 51(2), 151-166. http://dx.doi.org/10.1287/mnsc.1040.0333

Jin, Y., Vonderembse, M., Ragu-Nathan, T., \& Smith, J.T. (2014). Exploring relationships among IT-enabled sharing capability, supply chain flexibility, and competitive performance. International Journal of Production Economics, 153, 24-34.

Karuppan, C., \& Kepes, S. (2006): The strategic pursuit of mix flexibility through operators' involvement in decision making. International Journal of Operations and Production Management, 26(9), 1039-1064. http://dx.doi.org/10.1108/01443570610682625

Kim, D., Kumar, V., \& Kumar, U. (2012). Relationship between quality management practices and innovation. Journal of Operations Management, 30, 295-315. http://dx.doi.org/10.1016/j.jom.2012.02.003

Koste, L.L., \& Malhotra, M.K. (1999). A theoretical framework for analyzing the dimensions of manufacturing flexibility. Journal of Operations Management, 18(1), 75-93. http://dx.doi.org/10.1016/S02726963(99)00010-8

Liu, G., Shah, R., \& Schroeder, R. G. (2012). The relationships among functional integration, mass customisation, and firm performance. International Journal of Production Research, 50(3), 677-690. http://dx.doi.org/10.1080/00207543.2010.537390

Mackenzie, K.D. (1998). A framework for managing risky situations. International Journal of Organizational Analysis, 6(1), 5-31. http://dx.doi.org/10.1108/eb028876

Markus, M.L., Steinfield, C.W., \& Wigand, R.T. (2006). Industry-wide information systems standardization as collective action: the case of the US residential mortgage industry. MIS Quarterly, 30(1), 439-465.

Melville, N., Kraemer, K., \& Gurbaxani, V. (2004). Review: Information technology and organizational performance: an integrative model of IT business value. MIS Quarterly, 28(2), 283-322. 
Mihi-Ramírez, A., García-Morales V.J.; Arias-Aranda D. (2012): Knowledge creation and flexibility of distribution of information. Industrial Management \& Data Systems, 112(2), 166-185. http://dx.doi.org/10.1108/02635571211204245

Milgrom, P., \& Roberts, J. (1995). Complementarities and fit strategy, structure, and organizational change in manufacturing. Journal of Accounting and Economics, 19(2), 179-208. http://dx.doi.org/10.1016/01654101(94)00382-F

Milliken, F.J. (1987). Three types of perceived uncertainty about the environment: state, effect, and response uncertainty. Academy of Management Review, 12(1), 133-143.

Mitra, S., \& Chaya, A.K. (1996). Analyzing cost-effectiveness of organizations: the impact of information technology spending. Journal of Management Information Systems), 13(2), 29-57. http://dx.doi.org/10.1080/07421222.1996.11518122

Nelson, R.R., \& Winter S.G. (1982). Evolutionary theory of Economic Change. Cambridge, Mass.: Belknap Press.

New, C. (1996). The building blocks of manufacturing excellence. GEC Journal of Research, 13(2), 67-75.

Nunnally, J.C., \& Bernstein, I. (1978). Psychometric theory. New York: McGraw-Hill.

Nurmilaakso, J. (2008). Adoption of e-business functions and migration from EDI-based to XML-based e-business frameworks in supply chain integration. International Journal of Production Economics, 113(2), 721-733. http://dx.doi.org/10.1016/j.ijpe.2007.11.001

Oke, A. (2003). Drivers of volume flexibility requirements in manufacturing plants. International Journal of Operations \& Production Management, 23(12), 1497-1513. http://dx.doi.org/10.1108/01443570310506731

Oke, A. (2005). A framework for analysing manufacturing flexibility. International Journal of Operations \& Production Management, 25(9), 973-996. http://dx.doi.org/10.1108/01443570510619482

Petersen, K.J., Handfield, R.B., \& Ragatz, G.L. (2005). Supplier integration into new product development: coordinating product, process and supply chain design. Journal of Operations Management, 23(3), 371-388. http://dx.doi.org/10.1016/j.jom.2004.07.009

Podsakoff, P.M., Mackenzie, S.B., Lee, J.Y., \& Podsakoff, N.P. (2003). Common method biases in behavioral research: A critical review of the literature and recommended remedies. Journal of Applied Psychology, 88(5): 879-903. http://dx.doi.org/10.1037/0021-9010.88.5.879

Prahalad, C., \& Hamel, G. (1990). The core competence of the corporation. Boston (MA). 235-256. 
Ranganathan, C., Dhaliwal, J.S., \& Teo, T.S. (2004). Assimilation and diffusion of web technologies in supply-chain management: an examination of key drivers and performance impacts. International Journal of Electronic Commerce, 9(1), 127-161.

Ray, G., Muhanna, W.A., \& Barney, J.B. (2005). Information technology and the performance of the customer service process: a resource-based analysis. MIS Quarterly, 29(4), 625-652.

Sanders, N.R., \& Premus, R. (2002). IT applications in supply chain organizations: a link between competitive priorities and organizational benefits. Journal of Business Logistics, 23(1), 65-83. http://dx.doi.org/10.1002/j.2158-1592.2002.tb00016.x

Sawhney, R. (2006). Interplay between uncertainty and flexibility across the value-chain: towards a transformation model of manufacturing flexibility. Journal of Operations Management, 24(5), 476-493. http://dx.doi.org/10.1016/j.jom.2005.11.008

Schmenner, R.W., \& Tatikonda, M.V. (2005). Manufacturing process flexibility revisited. International Journal of Operations \& Production Management, 25(12), 1183-1189. http://dx.doi.org/10.1108/01443570510633585

Sethi, A.K., \& Sethi, S.P. (1990). Flexibility in manufacturing: a survey. International Journal of Flexible Manufacturing Systems, 2(4), 289-328. http://dx.doi.org/10.1007/BF00186471

Soroor, J., Tarokh, M.J., \& Keshtgary, M. (2009). Preventing failure in IT-enabled systems for supply chain management. International Journal of Production Research, 47(23), 6543-6557. http://dx.doi.org/10.1080/00207540802314837

Stank, T.P., Keller, S.B., \& Daugherty, P.J. (2001). Supply chain collaboration and logistical service performance. Journal of Business Logistics, 22(1), 29-48. http://dx.doi.org/10.1002/j.21581592.2001.tb00158.x

Stevens, G.C. (1989). Integrating the supply chain. International Journal of Physical Distribution \& Logistics Management, 19(8), 3-8. http://dx.doi.org/10.1108/EUM0000000000329

Stevenson, M., \& Spring, M. (2007). Flexibility from a supply chain perspective: definition and review. International Journal of Operations \& Production Management, 27(7), 685-713. http://dx.doi.org/10.1108/01443570710756956

Swafford, P.M., Ghosh, S., \& Murthy, N. (2008). Achieving supply chain agility through IT integration and flexibility. International Journal of Production Economics, 116(2), 288-297. http://dx.doi.org/10.1016/j.ijpe.2008.09.002 
Swafford, P.M., Ghosh, S., \& Murthy, N. (2006). The antecedents of supply chain agility of a firm: scale development and model testing. Journal of Operations Management, 24(2), 170-188.

http://dx.doi.org/10.1016/j.jom.2005.05.002

Swamidass, P.M., \& Newell, W.T. (1987). Manufacturing strategy, environmental uncertainty and performance: a path analytic model. Management Science, 33(4), 509-524.

http://dx.doi.org/10.1287/mnsc.33.4.509

Swanson, E.B. (1994). Information systems innovation among organizations. Management Science, 40(9), 1069-1092. http://dx.doi.org/10.1287/mnsc.40.9.1069

Szulanski, G. (1996). Exploring internal stickiness: Impediments to the transfer of the best practice within the firm. Strategic Management Journal, 17, 27-43. http://dx.doi.org/10.1002/smj.4250171105

Tam, K.Y. (1998). The impact of information technology investments on firm performance and evaluation: evidence from newly industrialized economies. Information Systems Research, 9(1), 85-98. http://dx.doi.org/10.1287/isre.9.1.85

Tanriverdi, H. (2006). Performance effects of information technology synergies in multibusiness firms. MIS Quarterly), 30(1), 57-77.

Teece, D.J., Pisano, G., \& Shuen, A. (1997). Dynamic capabilities and strategic management. Strategic Management Journal, 18(7), 509-533. http://dx.doi.org/10.1002/(SICI)1097-0266(199708)18:7<509::AIDSMJ882>3.0.CO;2-Z

Tu, Q., Vonderembse, M.A., Ragu-Nathan, T., \& Sharkey, T.W. (2006). Absorptive capacity: enhancing the assimilation of time-based manufacturing practices. Journal of Operations Management, 24(5), 692-710. http://dx.doi.org/10.1016/j.jom.2005.05.004

Upton, D.M. (1997). Process range in manufacturing: an empirical study of flexibility. Management Science, 43(8), 1079-1092. http://dx.doi.org/10.1287/mnsc.43.8.1079

Urgal-González, B., \& García-Vázquez, J.M. (2007). The strategic influence of structural manufacturing decisions. International Journal of Operations \& Production Management, 27(6), 605-626. http://dx.doi.org/10.1108/01443570710750286

Vickery, S., Droge, C., Setia, P., \& Sambamurthy, V. (2010). Supply chain information technologies and organisational initiatives: complementary versus independent effects on agility and firm performance. International Journal of Production Research, 48(23), 7025-7042. http://dx.doi.org/10.1080/00207540903348353 
Vokurka, R.J., \& O'Leary-Kelly, S.W. (2000). A review of empirical research on manufacturing flexibility. Journal of Operations Management, 18(4), 485-501. http://dx.doi.org/10.1016/S0272-6963(00)00031-0

Ward, P.T., Leong, G.K., \& Boyer, K.K. (1994). Manufacturing proactiveness and performance. Decision Sciences, 25(3), 337-358. http://dx.doi.org/10.1111/j.1540-5915.1994.tb01847.x

Zhang, C., \& Dhaliwal, J. (2009). An investigation of resource-based and institutional theoretic factors in technology adoption for operations and supply chain management. International Journal of Production Economics, 120(1), 252-269. http://dx.doi.org/10.1016/j.ijpe.2008.07.023

Zhang, Q., Vonderembse, M.A., \& Lim, J. (2003). Manufacturing flexibility: defining and analyzing relationships among competence, capability, and customer satisfaction. Journal of Operations Management,. 21, 2, 173-191. http://dx.doi.org/10.1016/S0272-6963(02)00067-0

Zhang, Q., Vonderembse, M.A., \& Cao, M. (2006). Achieving flexible manufacturing competence: the roles of advanced manufacturing technology and operations improvement practices. International Journal of Operations \& Production Management, 26(6), 580-599. http://dx.doi.org/10.1108/01443570610666957

Zhu, K. (2002). Information transparency in electronic marketplaces: Why data transparency may hinder the adoption of B2B exchanges. Electronic Markets, 12(2), 92-99.

http://dx.doi.org/10.1080/10196780252844535

Zhu, K., Kraemer, K.L., \& Xu, S. (2006). The process of innovation assimilation by firms in different countries: a technology diffusion perspective on e-business. Management Science,. 52(10),. 1557-1576. http://dx.doi.org/10.1287/mnsc.1050.0487

Journal of Industrial Engineering and Management, 2016 (www.jiem.org)

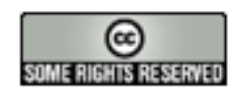

Article's contents are provided on an Attribution-Non Commercial 3.0 Creative commons license. Readers are allowed to copy, distribute and communicate article's contents, provided the author's and Journal of Industrial Engineering and Management's names are included. It must not be used for commercial purposes. To see the complete license contents, please visit http://creativecommons.org/licenses/by-nc/3.0/. 